\title{
DR. KIYOSHI MUTO
}

The name of Dr. Kiyoshi Muto is universally known in the field of earthquake engineering. His pre-eminent position has been achieved during not one, but two, distinguished careers.

Firstly, almost 40 years of his professional life were associated with the University of Tokyo where he became a lecturer immediately after graduating from the Faculty of Engineering in 1925. In 1931 the degree of Doctor of Engineering was conferred on him and in 1935 he became Professor of Architectural Engineering. In 1960 he was elected Dean of the Faculty of Engineering and, upon his retirement in 1963, the title of Professor Emeritus was conferred upon him.

Secondly, in the year of retirement from the University of Tokyo, he commenced his new career as an Executive Vice-President of the Kajima Corporation. This company was founded in 1840 and is, today, the largest general contracting firm in Japan and one of the leading contractors in the world. The number of technical personnel, approximately 7,000 (most of them university graduates), is a measure of the size of this organisation. Dr. Muto also directs the Muto Institute of Structural Mechanics, a group organised for and devoted to research into the behaviour of buildings under earthquake attack, whose contributions made possible the construction of Japan's first skyscraper, the 36 storey Kasumigaseki building, which was completed in 1968 . Associated with his company, in the practical field, is the Kajima Institute of Construction Technology which is well known to many New Zealand engineers who have had the privilege to visit this establishment and receive its technical publications.

No doubt, the disastrous 1923 Kanto Earthquake prompted the young Dr. Muto to develop an early interest in the design of structures and, in particular, to concentrate on the deformation of frames. From this came the application of $D$-values to the analysis of open frames. His publication of this work in 1929 was followed by its adoption as standard design practice by the Architectural Institute of Japan. A further extension of his D-values concept to include wall frames and seismic shear walls led Dr. Muto to present his findings to the First World Conference on Earthquake Engineering in 1956. Later, mainly as a result of the introduction in the SEAOC code of the triangular distribution of seismic loading, Dr. Muto materially revised his paper and published his "Seismic Analysis of Reinforced Concrete Buildings" in 1965. As recently as 1974 Dr. Muto published a further revised, more comprehensive version called "Aseismic Design Analysis of Buildings".
Dr. Muto's opinions and his organising ability have been sought from time to time by both national and international bodies concerned with earthquake engineering. For instance, he was one of three senior consultants representing the Japanese Government whose task was to establish a training and research programme for the International Institute of Seismology and Earthquake Engineering in Tokyo, which was jointly financed by UNESCO and the Japanese Government in 1963. Its purpose was to foster seismology and earthquake engineering in the developing countries and literally hundreds of students of many different nationalities have passed through his school. Two of our own National Society Members - Dr. Bruce H. Falconer and Mr. R. I. Skinner - were UNESCO Experts on its staff.

Dr. Muto was also associatied in the development of the SMAC strong motion accelerographs in Japan and the establishing of a net-work of such instruments throughout the country, which has contributed so much to the dynamic analysis of modern buildings.

Again of interest to New Zealand Engineers and Architects is the fact that Dr. Muto was the first chairman of the Special Review Committee for Structural Design of High Rise Buildings in Japan. In 1964 the Ministry of Construction asked Dr. Muto to set up such a committee with representations from the Universities, Ministry of Construction (Research Institute), large construction companies and from experienced practising consulting engineers. This committee is still functioning and has completed reviews of more than 250 tall buildings.

When Japan introduced its first commercial nuclear power plant (Improved Calder Hall type) from England, Dr. Muto led the seismic design team and compiled the first Japanese seismic specifications for such power plants in 1974. Recently, he has been studying the designs, vibration tests and earthquake observations of many plants of Boiling Water Reactor type (B.W.R.) and new High Temperature Gas-cooled Reactor type (H.T.G.R.).

Dr. Muto has an impressive record of service to the International Association for Earthquake Engineering having attended and read at least one paper to each of the five World Conferences. He presided over one of them, the Third World Conference, which was held in New Zealand. Recognising his contributions, the IAEE honoured him with Life Membership, an honour rarely given.

Dr. Muto's vigorous interest in earthquake engineering has never flagged - from his initial investigation of D-values; his research into the ultimate strength of 
reinforced concrete (which, in 1944, resulted in Japanese standards on this subject); to his present day research into the design of skyscrapers and atomic reactors.

The members of the N.Z. National Society for Earthquake Engineering were privileged to welcome Dr. Muto to its South Pacific Regional Conference and expressed their appreciation of his past and continuing con- tributions to the world's fund of earthquake engineering knowledge. The Management Committee of the Society had much pleasure in electing Dr. Muto a Life Member of the N.z. National Society for Earthquake Engineering. This carried with it the sincere congratulations of all members and the hope that Dr. Muto would have many more fruitful years in his chosen profession of earthquake engineering.

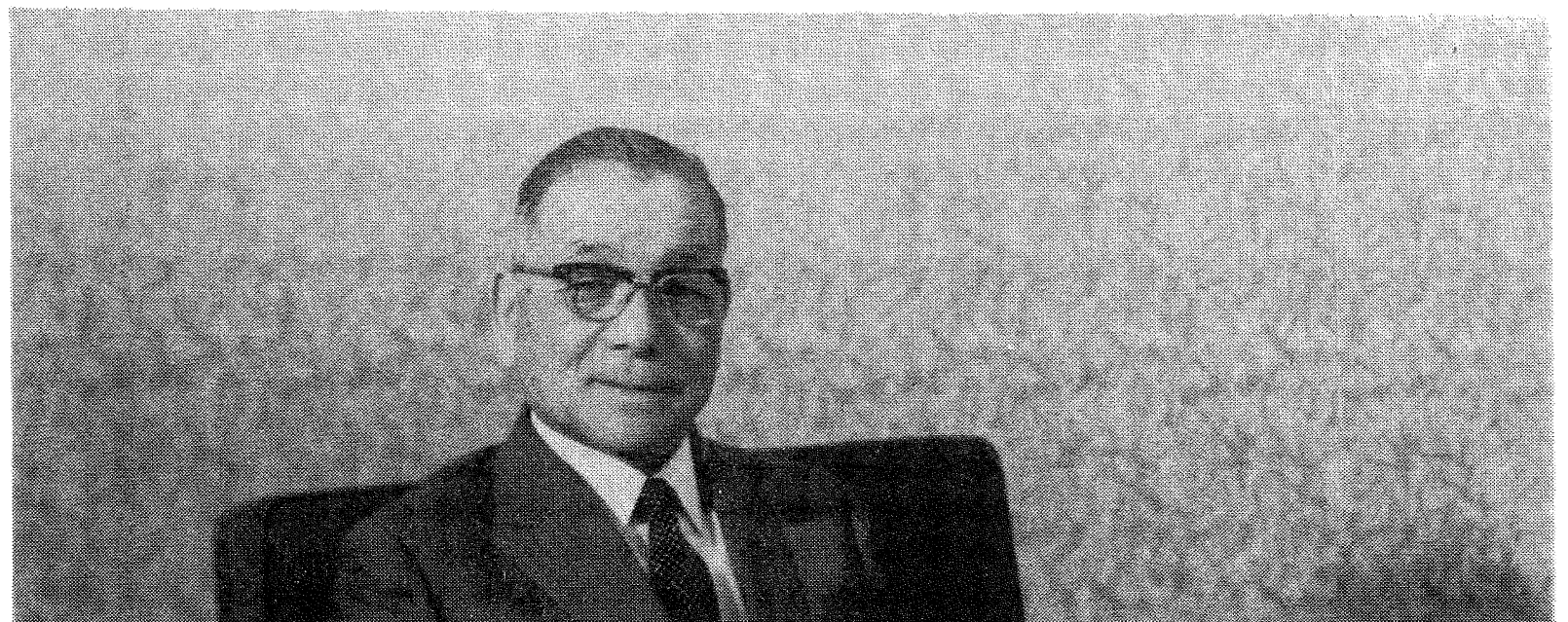

